\title{
Betere prestaties door samen prestatie-indicatoren te ontwikkelen
}

\section{Bianca Groen}

SAMENVATTING Uit onderzoek is gebleken dat medewerkersprestaties kunnen verbeteren door samen met medewerkers prestatie-indicatoren te ontwikkelen. Onbekend is hoe deze verbetering precies tot stand komt, terwijl organisaties dat juist moeten weten als zij hetzelfde willen bereiken. Dit artikel test twee mogelijke verklaringen. Uit drie verschillende studies blijkt dat zowel medewerkers als leidinggevenden de kwaliteit van samen ontwikkelde prestatie-indicatoren hoger vinden. Verder blijkt dat kwalitatief goede prestatie-indicatoren medewerkers beter in staat stellen om goed te presteren en ze helpen leidinggevenden om discussies aan te gaan met medewerkers over hun prestaties. Dit zorgt allebei voor betere prestaties van medewerkers.

RELEVANTIE VOOR DE PRAKTIJK Dit onderzoek geeft organisaties inzicht in hoe medewerkersprestaties kunnen verbeteren door medewerkers te betrekken bij het ontwikkelen van prestatie-indicatoren. Daarnaast bevat dit artikel een omschrijving van hoe zo'n ontwikkelingstraject kan worden vormgegeven.

\section{Inleiding}

Verschillende onderzoeken hebben aangetoond dat medewerkersprestaties verbeterd kunnen worden door samen met medewerkers prestatie-indicatoren te ontwikkelen (Abernethy en Bouwens, 2005; Hunton en Gibson, 1999; Kleingeld, Van Tuijl en Algera, 2004). Deze onderzoeken gaan ervan uit dat medewerkers dan beter presteren doordat samen prestatie-indicatoren ontwikkelen een positieve invloed heeft op hun gedrag. Gebaseerd op eerdere bevindingen in de algemene literatuur op het gebied van medewerkersparticipatie en ook specifiek voor participatie in goal setting nemen Kleingeld, Van Tuijl en Algera (2004) aan dat hier motivationele en cognitieve factoren aan ten grondslag liggen (Latham, Winters en Locke, 1994; Wagner, Leana, Locke en Schweiger, 1997). Andere studies laten zien dat ook sociale effecten belangrijk kunnen zijn in deze relatie (Erez en Arad, 1986; Jeong, 2006).
Voor verschillende soorten participatie zijn verschillende effecten te verwachten (Jeong, 2006). Om ook andere organisaties te laten profiteren van de mogelijk positieve effecten van samen prestatie-indicatoren ontwikkelen, is het belangrijk om te weten waar die effecten vandaan komen. Voor het specifieke geval van prestatie-indicatoren ontwikkelen samen met medewerkers is dit nog niet empirisch onderzocht. In het huidige onderzoek staat daarom de volgende vraag centraal: Waarom gaan medewerkers beter presteren als ze worden betrokken bij het maken van de prestatieindicatoren die worden gebruikt om hun prestaties te meten? In dit onderzoek worden twee modellen getest ter verklaring van de relatie tussen samen prestatie-indicatoren maken en medewerkersprestaties.

\subsection{Wat zijn prestatie-indicatoren?}

Om goed te begrijpen waar dit artikel over gaat, is het belangrijk om te weten wat hier wordt bedoeld met prestatie-indicatoren. In de basis komt het hier op neer: prestatie-indicatoren zijn alles wat gebruikt wordt om de werkprestaties van medewerkers kwantitatief mee uit te drukken. In dit onderzoek wordt alleen gekeken naar prestatie-indicatoren van uitvoerende medewerkers in het primaire proces van de organisatie. Voorbeelden van zulke medewerkers zijn: advocaten, artsen, bouwvakkers, callcentermedewerkers, chauffeurs, consultants, docenten, horecamedewerkers, ICT'ers, logistiek medewerkers, monteurs, operators, technici, verkopers, verplegers, etc. Een specifiekere definitie van een prestatie-indicator is: een meetinstrument dat gebruikt wordt om de effectiviteit of efficiëntie van acties te kwantificeren (Neely, Gregory en Platts, 1995).

Met "het samen ontwikkelen van prestatie-indicatoren" wordt bedoeld dat medewerkers een substantiële hoeveelheid invloed krijgen in het ontwerp, de implementatie en de doorontwikkeling van de prestatie-indicatoren die gebruikt worden om hun prestaties te meten. Het gaat hierbij dus niet alleen om participatie in het stellen van het doel, maar ook om het ontwerp van alle andere onderdelen van de prestatie-indicatoren: de naam (wat wil je me- 
ten?), de formule, de databronnen, de koppeling aan een hoger doel, en de afspraken over hoe vaak er gemeten wordt en wie waarvoor verantwoordelijk is (zie Neely, Bourne, Mills, Platts en Richards, 2002; Neely, Richards, Mills, Platts en Bourne, 1997).

\subsection{Opbouw van dit artikel}

Dit artikel beschrijft drie verschillende studies die antwoord geven op de vraag waarom medewerkers beter gaan presteren als ze worden betrokken bij het maken van hun eigen prestatie-indicatoren. Paragraaf 2 gaat over een onderzoek in een middelgroot productiebedrijf. In dat bedrijf heb ik samen met de monteurs van de bottelarij prestatie-indicatoren ontwikkeld. Door deze ervaringen te combineren met bestaande theorieën heb ik een verklarend model opgesteld voor de relatie tussen samen prestatie-indicatoren ontwikkelen en medewerkersprestaties. Bovendien heeft dit actie-onderzoek geleid tot een stappenplan dat andere organisaties kan helpen om zelf ook zinvolle prestatie-indicatoren te ontwikkelen samen met medewerkers.

Het verklarende model dat het initiële actie-onderzoek heeft opgeleverd is verder onderzocht met een vragenlijstonderzoek onder paren van medewerkers en leidinggevenden in allerlei verschillende soorten banen, organisaties en sectoren. Paragraaf 3 vat dit onderzoek samen en geeft daarmee meer inzicht in de positieve gevolgen voor medewerkers van het samen ontwikkelen van prestatie-indicatoren die uiteindelijk leiden tot betere prestaties. Paragraaf 4 is ook gebaseerd op ditzelfde vragenlijstonderzoek, maar beantwoordt de centrale vraag vanuit een heel ander perspectief. Hierin wordt gekeken naar hoe leidinggevenden omgaan met samen met medewerkers ontwikkelde prestatie-indicatoren en hoe dat weer leidt tot betere prestaties van medewerkers. In paragraaf 5 worden de bevindingen van de drie studies besproken.

\section{Samen prestatie-indicatoren ontwikkelen ${ }^{1}$}

De eerste studie naar een verklaring voor het verband tussen samen prestatie-indicatoren ontwikkelen en medewerkersprestaties vond plaats in een middelgroot productiebedrijf. Het hoofd van de afdeling 'supply' wilde graag dat de monteurs van de bottelarij meer initiatieven voor verbetering van de bottelarij zouden gaan nemen en dat ze daarmee de prestaties van de bottelarij zouden verhogen. Op basis van eerdere projecten binnen de organisatie (zie bijvoorbeeld Wouters en Wilderom, 2008) was hij ervan overtuigd dat dit mogelijk was door samen met die monteurs prestatie-indicatoren te ontwikkelen. Als projectleider van dit project kreeg ik hiermee de unieke kans om in de praktijk te onderzoeken hoe het komt dat medewerkers meer verbeterinitiatieven gaan nemen als ze worden betrokken bij het maken van hun eigen prestatieindicatoren en hoe prestaties als gevolg hiervan verbeteren.
Voor het beantwoorden van deze vraag leek de theory of planned behavior relevant (Ajzen, 1991; door Fishbein en Ajzen, 2010 en Ajzen, 2012 ook wel het reasoned action model genoemd). Deze theorie wordt veel gebruikt om allerlei soorten menselijk gedrag te verklaren, voorspellen en veranderen. Volgens de theorie zijn er drie factoren van invloed op iemands gedrag: iemands houding ten opzichte van het gedrag (attitude), de sociale druk die iemand voelt om het gedrag uit te voeren (norm) en de mate waarin iemand denkt in staat te zijn om het gedrag uit te voeren (control). Deze vertonen grote overlap met de in de inleiding genoemde motivationele, sociale en cognitieve factoren die in andere participatieliteratuur is gebruikt om het verband met prestatie te verklaren. In dit onderzoek was het specifieke gedrag "meer verbeterinitiatieven nemen" en er is gekeken in hoeverre deze drie factoren positief beïnvloed werden door samen met medewerkers prestaties te ontwikkelen.

\subsection{Methode}

Dit onderzoek maakte gebruik van actie-onderzoek, omdat het daarmee mogelijk is om gedetailleerd en praktisch relevant inzicht te verkrijgen in het proces dat uiteindelijk heeft geleid tot een verbetering (Coughlan en Coghlan, 2002; Kasanen, Lukka en Siitonen, 1993). De specifieke vorm van actie-onderzoek die we gebruikten heet clinical field work (Baskerville en Wood-Harper, 1998). Dat houdt in dat de onderzoeker de organisatie helpt een bepaald probleem op te lossen (Schein, 1987). In dit geval was het 'probleem' volgens het afdelingshoofd dat de monteurs te weinig verbeterinitiatieven vertoonden. Dit probleem werd aangepakt door prestatie-indicatoren te ontwikkelen samen met alle 34 monteurs. Tijdens dit proces werd op basis van interviews, observaties en vragenlijsten bekeken hoe dit ontwikkelproces leidde tot veranderingen in attitude, norm en control van de monteurs en uiteindelijk tot meer verbeterinitiatieven. Verder werd op basis van archiefdata gekeken of het samen ontwikkelen van prestatie-indicatoren ook echt leidde tot verbeteringen in de afdelingsprestaties.

\subsection{Het ontwikkelproces}

Deze paragraaf beschrijft de ontwikkeling van de prestatie-indicatoren samen met de medewerkers. Dit is niet alleen een belangrijk onderdeel van de methode, maar ook een resultaat op zich. Andere organisaties kunnen deze omschrijving gebruiken om ook hun medewerkers te betrekken bij de ontwikkeling van prestatie-indicatoren. Belangrijk voor het ontwikkelproces was dat er vanaf het begin een onafhankelijke projectleider was aangesteld (Wouters, 2009). Tijdens de ontwikkelingsbijeenkomsten met medewerkers nam deze projectleider een gebalanceerde rol in. Aan de ene kant trad zij op als coach om zo de medewerkers voldoende de ruimte te geven om hun eigen ideeën in de prestatie-indicatoren tot uitdrukking te laten komen. En tegelijkertijd was zij de expert die 
ideeën aandroeg om te laten zien wat er allemaal mogelijk was.

Samen prestatie-indicatoren ontwikkelen houdt in dat medewerkers veel vrijheid krijgen in de bepaling van de uiteindelijke prestatie-indicatoren. Tegelijkertijd is het ook belangrijk om ervoor te zorgen dat de prestatie-indicatoren aansluiten bij de doelen van de organisatie. Daarom zijn van te voren de doelen van het project bepaald: het project moest leiden tot meer verbeterinitiatieven van monteurs en tot prestatieverbetering van de bottelarij. Verder was vooraf bepaald in welke richtingen prestatie-indicatoren moesten worden gemaakt, zodat de indicatoren aan zouden sluiten bij de doelen van de organisatie. Daartoe waren vier verschillende themagroepen gemaakt: energieverbruik, materiaalverlies, storingen en planmatig onderhoud.

Het eerste contact met de monteurs over dit project was een nieuwsbrief vlak voor de zomervakantie. Vervolgens hield de projectleider met iedere monteur een persoonlijk gesprek. Het project zelf bestond uit verschillende bijeenkomsten met iedere themagroep. In de eerste bijeenkomst van elke groep werden met behulp van een 'brainwrite' zoveel mogelijk verbeterideeën bedacht binnen het thema van de groep. Voor de tweede bijeenkomst had de projectleider de verbeterideeën gecategoriseerd en besproken met de leidinggevenden van de monteurs. In de bijeenkomst bespraken de monteurs de verbeterideeën en gaven ze aan welke drie categorieën het meest relevant waren om prestatie-indicatoren voor te maken.

In de volgende sessies werden de prestatie-indicatoren zelf ontwikkeld. Aan de hand van de criteria van Neely et al. (2002) werd besloten hoe de indicatoren moesten gaan heten, aan welke doelen van de organisatie ze gerelateerd zijn, welke data gebruikt worden en hoe die data worden weergegeven, welk target de monteurs wilden halen, hoe vaak de indicatoren geüpdatet en besproken moeten worden en wie daar verantwoordelijk voor is. Uiteindelijk waren de volgende prestatie-indicatoren gemaakt: (1) uitstoot door ondervulling, (2) legeflessenuitstoot, (3) waterverbruik, (4) persluchtverbruik en (5) electriciteitsverbruik. Tussen de sessies in creëerde de projectleider steeds prototypes gebaseerd op bestaande data uit de informatiesystemen van de organisatie, waarin al deze ideeën verwerkt waren. De prototypes werden direct gebruikt alsof ze al af waren: ze werden elke maand besproken tijdens een van de bijeenkomsten van de monteurs met hun leidinggevenden die iedere ochtend plaatsvinden. Zo was het mogelijk om elke keer een concrete discussie te houden over wat er nog beter aan kon.

\subsection{Bevindingen}

Op het moment dat de monteurs hoorden dat ze binnenkort prestatie-indicatoren zouden moeten gaan maken, reageerden ze erg negatief: "dat is toch helemaal niet mogelijk voor zo'n ingewikkeld proces”, was de eerste reactie die ik hoorde van een monteur. En de tweede reactie, van een andere monteur, was: "ik vind het helemaal niet nodig om beoordeeld te worden". Na afloop van het ontwikkelproces waren ze veel positiever. Ze begrepen toen hoe nuttig prestatie-indicatoren voor hen konden zijn. Voorbeelden van reacties tijdens de evaluatiesessies waren: "van te voren had ik geen idee wat een KPI was, nu weet ik dat beter" en "je ziet nu ongeveer waar je mee bezig bent qua cijfers en geld".

De ontwikkeling van prestatie-indicatoren samen met de monteurs van de bottelarij had verschillende positieve gevolgen. Allereerst zagen we dat de monteurs meer initiatieven namen om de prestaties van de bottelarij te verbeteren. Dit was terug te zien in de scores op de gemaakte prestatie-indicatoren die op basis van de data in de meetsystemen van de organisatie konden worden gereconstrueerd voor de periode voordat de prestatie-indicatoren waren ontwikkeld. Direct de maand nadat de prestatie-indicatoren in gebruik werden genomen gingen de prestaties op die indicatoren omhoog.

Op basis van gesprekken met de monteurs en hun leidinggevenden vonden we hier verschillende verklaringen voor, die overeenkomen met wat volgens de theory of planned behavior belangrijk is om gedrag van mensen te beïnvloeden: ze kregen een positievere houding ten opzichte van verbeterinitiatieven nemen (attitude), ze voelden meer sociale druk om verbeterinitiatieven te nemen (norm), en de nieuw ontwikkelde prestatie-indicatoren stelden medewerkers beter in staat om hun werk goed te doen (control). Een vragenlijstonderzoek onder de monteurs liet zien dat deze drie variabelen inderdaad gerelateerd zijn aan verbetergedrag $(r$ (attitude - verbetergedrag) $=0,58, \mathrm{p}<0,01$; $r$ (norm - verbetergedrag) $=0,43, \mathrm{p}<0,05 ; r$ (control verbetergedrag) $=0,38, \mathrm{p}<0,05)^{3}$

De monteurs gaven aan dat ze - nu er gebruik werd gemaakt van prestatiemeting - eindelijk erkenning kregen voor het werk dat ze verrichten. Al hun inspanningen werden direct zichtbaar in de prestatie-indicatoren en dit was op zich al heel motiverend, maar dit effect werd nog eens versterkt doordat de leidinggevenden van de monteurs dit gebruikten om de monteurs te complimenteren met hun goede werk. Deze erkenning van hun inspanningen zorgde ervoor dat de monteurs een positievere houding kregen ten opzichte van verbeterinitiatieven nemen. Opvallend was dat de motivatie van monteurs om te verbeteren vooral omhoog ging toen de prestatie-indicatoren ook inzichtelijk maakten hoeveel geld er bespaard kon worden.

Een tweede positief gevolg van het samen ontwikkelen van prestatie-indicatoren was dat de monteurs meer sociale druk voelden om verbeterinitiatieven te nemen. De prestatie-indicatoren maakten het mogelijk om concrete doelen te stellen en daardoor beter te weten wat er van elkaar verwacht werd. Toen de monteurs bijvoorbeeld zagen dat ze op een bepaalde productielijn een hogere uitstoot door ondervulling hadden dan op andere vergelijk- 
bare lijnen, deden ze er alles aan om die lijn op hetzelfde niveau te krijgen.

Verder stelden de nieuw ontwikkelde prestatie-indicatoren medewerkers op allerlei manieren beter in staat om hun werk goed te doen. De indicatoren gaven bijvoorbeeld inzicht in waar de meeste verbetering mogelijk was, waardoor monteurs beter prioriteiten konden stellen en waardoor ze ook meer ondersteuning kregen van hun leidinggevenden om die verbeteringen door te voeren (met name in de zin van geld en tijd). Daarnaast vormden de prestatie-indicatoren elke maand een onderwerp van discussie, waardoor de monteurs en hun leidinggevenden meer informatie uitwisselden. Dit zorgde er allemaal voor dat de monteurs ook echt de mogelijkheid hadden om verbeterinitiatieven te ontplooien. Overigens was er één indicator gemaakt waarvan de monteurs niet geloofden dat zij invloed hadden op de score. En ze slaagden er inderdaad niet in de score op die indicator te verbeteren. Hieruit blijkt dat control essentieel is om meer verbeterinitiatieven te nemen. Dit correspondeert met de resultaten op de vragenlijst die de monteurs hebben ingevuld. Uit een regressieanalyse bleek dat als alle variabelen tegelijkertijd worden meegenomen in de analyse alleen control significant gerelateerd was aan medewerkersinitiatief $(\beta=0,38, p<$ $0,05)$.

Een laatste positief uitvloeisel van samen met de monteurs prestatie-indicatoren ontwikkelen, was dat de kwaliteit van die prestatie-indicatoren veel beter was en bleef dan wanneer de monteurs geen invloed zouden hebben gehad. De monteurs bleken bijvoorbeeld veel verstand te hebben van welke gegevensbronnen het meest relevant zouden zijn. Bovendien zagen de monteurs het - toen de prestatie-indicatoren in gebruik waren - onmiddellijk als er iets mis was met de meters waarop de prestatie-indicatoren gebaseerd waren. Omdat ze geloofden in het nut van een goede meting, namen ze bij een defecte meter nu direct actie.

\subsection{Discussie}

Samengevat liet dit actie-onderzoek zien dat de theory of planned behavior kan verklaren waarom medewerkers meer verbeterinitiatieven gaan ontplooien als ze zijn betrokken bij het maken van hun eigen prestatie-indicatoren. Nadat de medewerkers van deze studie samen prestatie-indicatoren ontwikkeld hadden, kregen ze een positievere houding ten aanzien van het nemen van verbeterinitiatieven, voelden ze meer sociale druk om verbeterinitiatieven te nemen en voelden ze zich beter in staat om meer verbeterinitiatieven te nemen. Deze drie factoren bleken allemaal gerelateerd aan de mate waarin medewerkers verbeterinitiatieven nemen en statistisch gezien lijkt de derde de belangrijkste te zijn.

Sterk aan deze studie is dat het een diepgaand inzicht geeft in hoe prestatie-indicatoren ontwikkelen samen met medewerkers in de praktijk uitwerkt. Beperkingen zijn dat de resultaten gebaseerd zijn op slechts één afdeling binnen één bedrijf en dat het onmogelijk was om de participatieve manier van prestatie-indicatoren maken te vergelijken met een top-down manier. In antwoord op deze beperkingen is in paragraaf 3 gebruik gemaakt van een groot cross-sectioneel vragenlijstonderzoek onder een veel bredere groep respondenten.

\section{Gevolgen van samen prestatie-indicatoren ontwikkelen voor de medewerker}

In combinatie met verdere literatuur heeft het onderzoek in paragraaf 2 geleid tot een model dat - vanuit het perspectief van de medewerker - kan verklaren waarom medewerkersprestaties kunnen verbeteren als medewerkers worden betrokken bij het maken van hun eigen prestatieindicatoren. Een schematische weergave van dit model is te vinden in Figuur 1. Het model bestaat uit zeven hypotheses. Allereerst wordt verwacht dat medewerkers de kwaliteit van prestatie-indicatoren beter vinden als zij zijn betrokken bij het maken van prestatie-indicatoren (hypothese 1). Dit komt enerzijds doordat medewerkers waardevolle unieke informatie bezitten over hun werk die

Figuur 1 Schematische weergave van het verklarende model voor de relatie tussen medewerkers betrekken bij de ontwikkeling van prestatie-indicatoren en medewerkersprestaties vanuit het perspectief van medewerkers, inclusief gestandaardiseerde padcoëfficiënten

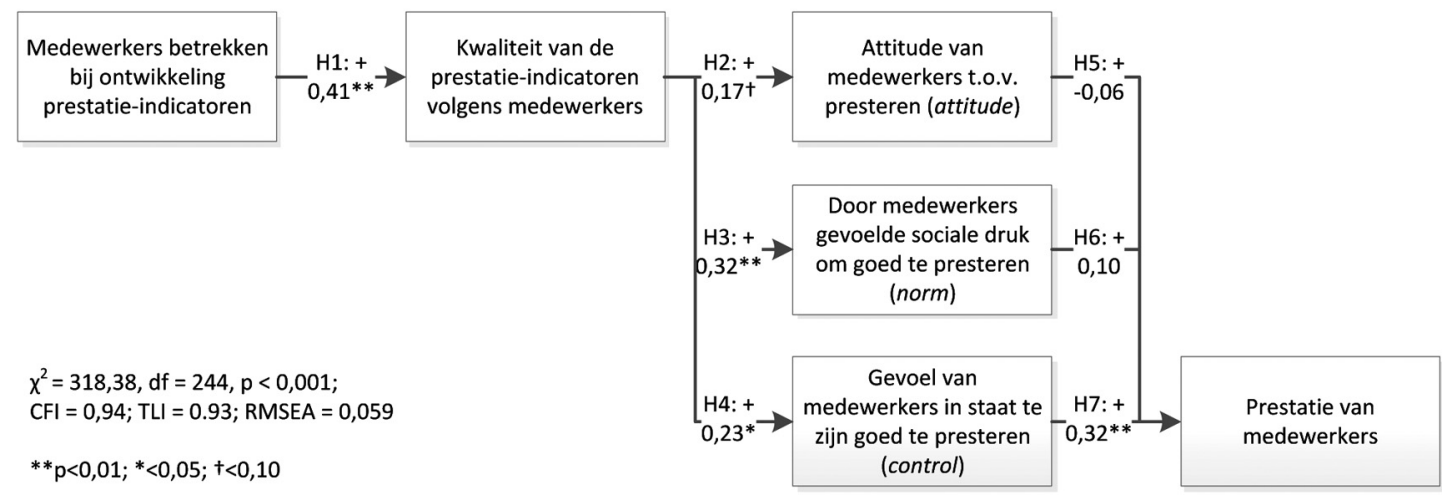


alleen opgenomen kan worden in de prestatie-indicatoren als zij betrokken zijn bij de ontwikkeling ervan. Anderzijds zullen medewerkers positiever zijn over indicatoren omdat hun eigen inzichten en overtuigingen erin zijn verwerkt. Verder wordt verwacht dat als medewerkers vinden dat de prestatie-indicatoren van goede kwaliteit zijn, dat ze dan ook een positievere houding (attitude) krijgen ten opzichte van presteren (hypothese 2), met name omdat ze dan streven naar doelen die ze zelf ook belangrijk vinden. Verder zullen ze meer sociale druk (norm) voelen om goed te presteren (hypothese 3), omdat ook mensen in hun werkomgeving de samen opgestelde doelen graag willen halen. Tot slot stellen goede prestatie-indicatoren mensen beter in staat om goed te presteren (control, hypothese 4). Dit komt vooral doordat de prestatie-indicatoren mensen kunnen ondersteunen bij het maken van goede beslissingen. In lijn met de theory of planned behavior wordt verwacht dat deze factoren alle drie zorgen voor hogere medewerkersprestaties (hypothese $5 \mathrm{t} / \mathrm{m} 7$ ).

\subsection{Methode}

De hypotheses werden statistisch getoetst met structural equation modeling aan de hand van de met een vragenlijst verzamelde data. Er was voor gezorgd dat de data en de bijbehorende resultaten zo betrouwbaar mogelijk zouden zijn door de vragenlijst van te voren goed te testen en door er alles aan te doen om te voorkomen dat er common method bias zou zijn. Bovendien zijn er verschillende controles gedaan om te kijken of de gevonden resultaten robuust zijn.

De vragenlijst was ingevuld door paren van medewerkers en hun leidinggevenden die aan de volgende criteria voldeden: (1) ze werkten al minimaal een jaar in hun huidige functie, (2) de medewerkers hadden een uitvoerende functie in het primaire proces van de organisatie en (3) de leidinggevenden gebruikten prestatie-indicatoren om de prestaties van hun medewerker te meten. Omdat het onmogelijk was om vóór het nemen van een steekproef te weten wie aan deze criteria voldeed, werd gebruik gemaakt van een sneeuwbalsteekproef: mensen die aan het onderzoek meewerkten werden gevraagd om ook anderen te noemen die aan deze criteria voldoen (Salganik en Heckathorn, 2004). Uiteindelijk hadden 95 medewerkers en 88 leidinggevenden de vragen ingevuld die voor dit model relevant waren en daarmee beschikten we over de data van 88 complete paren. Deze respondenten waren werkzaam in allerlei soorten functies, organisaties en sectoren. De paarsgewijze opzet maakte het mogelijk om de constructen te meten bij de voor dat construct relevante persoon en tegelijkertijd verkleinde het de kans dat de resultaten het gevolg zijn van common method bias. In dit model is de score op de afhankelijke variabele (prestatie) afkomstig van de leidinggevende en de rest van de variabelen zijn gemeten bij de medewerker.

De mate waarin medewerkers betrokken zijn bij de ontwikkeling van de prestatie-indicatoren waarmee hun pres- tatie gemeten wordt, werd in dit onderzoek gemeten met de bestaande schaal van Abernethy en Bouwens (2005; Cronbachs alfa $=0,94)$. Voor de kwaliteit van de prestatieindicatoren zijn vijf items van Moers (2006) gebruikt die meten hoe gevoelig de indicatoren zijn voor de acties van de medewerkers, hoe precies ze relevante aspecten van hun prestatie meten en hoe verifieerbaar ze zijn (Cronbachs alfa $=0,80$ ). De schalen voor attitude, norm en control hebben we zelf geconstrueerd op basis van de richtlijnen die er zijn voor het ontwikkelen van theory-ofplanned-behaviorvragenlijsten (Darker en French, 2009; Fishbein en Ajzen, 2010; Francis et al., 2004). Cronbachs alfas waren 0,87 voor attitude; 0,86 voor norm; en 0,61 voor control. Medewerkersprestaties werden gemeten met de veelgebruikte door Podsakoff en MacKenzie (1989) tot vijf items ingekorte schaal van Williams en Anderson (1991) die in eerdere onderzoeken een grote samenhang met objectieve prestatie vertoonde (Burney, Henle en Widener, 2009; Cronbachs alfa $=0,91$ ).

\subsection{Bevindingen}

Figuur 1 geeft de resultaten van het onderzoek. De diverse robuustheidscontroles die we hebben gedaan zijn consistent hiermee. Allereerst wordt hypothese 1 ondersteund. Dat wil zeggen dat participatie van medewerkers in het ontwikkelen van prestatie-indicatoren zorgt voor prestatie-indicatoren die volgens medewerkers een hoge kwaliteit hebben. Verder blijken kwalitatief goede prestatie-indicatoren zoals verwacht gerelateerd te zijn aan een hogere attitude, norm en control (hypotheses $2 \mathrm{t} / \mathrm{m} \mathrm{4}$ ). Anders dan verwacht worden hypotheses 5 en 6 niet ondersteund door de data. Er is wel een verband gevonden tussen control en medewerkersprestaties (hypothese 7). Samengevat komt het erop neer dat medewerkersprestaties kunnen worden bevorderd door samen prestatie-indicatoren te ontwikkelen omdat de kwaliteit van prestatie-indicatoren in de ogen van medewerkers hierdoor kan worden verhoogd, en doordat kwalitatief goede prestatie-indicatoren medewerkers beter in staat stellen om goed te presteren.

\section{Gevolgen van samen prestatie-indicatoren ontwikkelen voor de leidinggevende}

Paragraaf 3 onderzocht een verklarend model voor hoe samen met medewerkers prestatie-indicatoren ontwikkelen kan leiden tot betere prestaties van medewerkers vanuit het perspectief van de medewerker zelf. Deze paragraaf onderzoekt hetzelfde verband, maar dan gezien vanuit leidinggevenden. Het theoretische verklarende model is weergegeven in figuur 2. Op basis van de agency theory (zie voor een uitgebreide uitleg van deze theorie Eisenhardt, 1989; Kunz en Pfaff, 2002; Lambert, 2007) en self-determination theory (Ryan en Deci, 2000) zijn acht hypotheses opgesteld. Hypothese 1 gaat ervan uit dat ook leidinggevenden vinden dat de kwaliteit van prestatie-indicatoren beter is als medewerkers worden betrokken bij de ontwikkeling ervan. Dit komt omdat dan de specifieke kennis die mede- 
Figuur 2 Schematische weergave van het verklarende model voor de relatie tussen medewerkers betrekken bij de ontwikkeling van prestatie-indicatoren en medewerkersprestaties vanuit het perspectief van leidinggevenden, inclusief gestandaardiseerde padcoëfficiënten

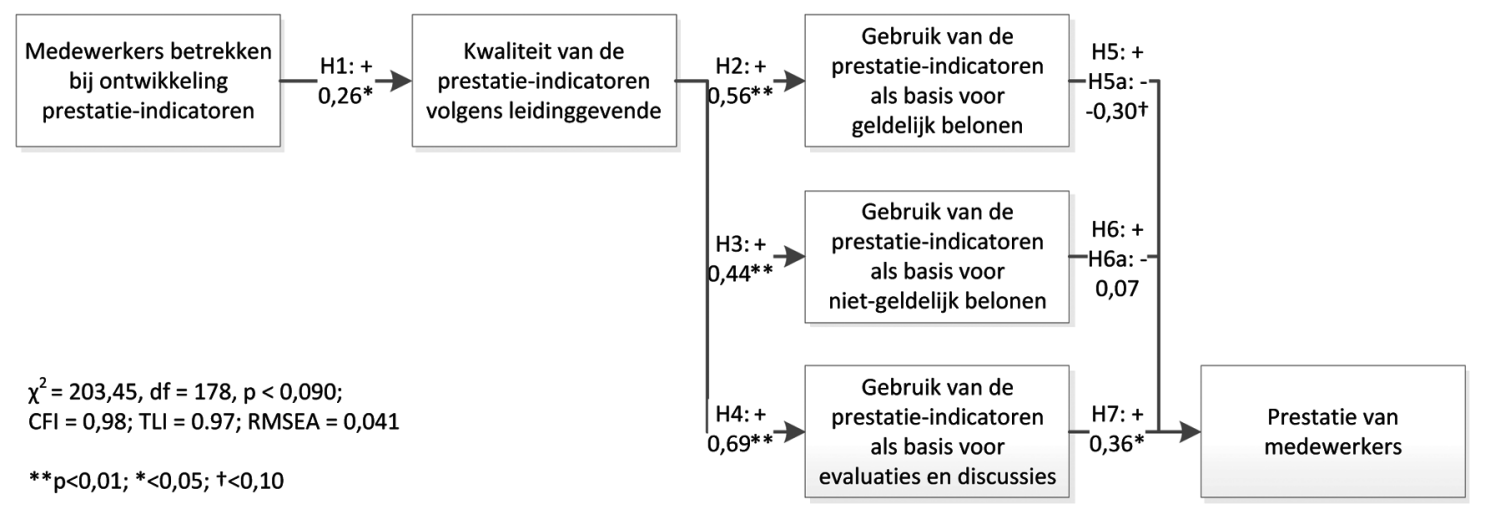

werkers hebben over hun werk kan worden geïntegreerd in de prestatie-indicatoren. Ook medewerkers hebben hier belang bij: als de prestatie-indicatoren hun prestaties goed weergeven, zullen ze meer erkenning krijgen voor hun inspanningen.

Voor leidinggevenden zijn prestatie-indicatoren vooral nuttig omdat ze gebruikt kunnen worden om in de gaten te houden of medewerkers hun werk wel goed doen en om op basis daarvan medewerkers al dan niet te belonen. Hoe beter de kwaliteit van de prestatie-indicatoren, hoe beter de indicatoren gebruikt kunnen worden als basis voor beoordeling en beloning van medewerkers. We maken onderscheid in verschillende soorten beloningen: geldelijk belonen, niet-geldelijk belonen in de vorm van het geven van promotie of meer verantwoordelijkheden, en verbale beloningen in de vorm van het evalueren en bediscussiëren van iemands prestaties. Hypotheses 2 tot en met 4 stellen dat leidinggevenden de prestatie-indicatoren eerder zullen gebruiken voor alle vormen van belonen als zij van betere kwaliteit zijn.

In principe zijn alle soorten beloningen bedoeld om de kloof te dichten tussen wat medewerkers willen bereiken en wat de organisatie wil bereiken. Met andere woorden, ze proberen medewerkers te stimuleren om beter te presteren. Dit komt overeen met de agency theory en leidt tot hypotheses 5 tot en met 7: naarmate leidinggevenden de prestatie-indicatoren meer gebruiken om medewerkersbeloningen op te baseren zullen medewerkers gemiddeld beter presteren. Het komt echter ook voor dat de belangen van medewerkers en organisaties niet zo ver uitelkaar liggen. In dat geval zijn medewerkers vaak intrinsiek gemotiveerd om goed te presteren en verdwijnt de noodzaak om ze te stimuleren om beter te presteren. Sterker nog, als mensen al intrinsiek gemotiveerd zijn, kunnen extrinsieke beloningen juist zorgen voor een lagere motivatie en als gevolg daarvan prestatie (Deci, Koestner en Ryan, 1999; Falk en Kosfeld, 2006; Gagné en Deci, 2005; Wong-On-
Wing, Guo en Lui, 2010). Op basis hiervan wordt verwacht dat de extrinsieke geldelijke en niet-geldelijke beloningen zullen leiden tot een verlaging van medewerkersprestaties (hypotheses 5a en 6a). Voor hypothese 7 wordt geen alternatieve hypothese opgesteld, want self-determination theory verwacht dezelfde relatie tussen verbale beloningen en medewerkersprestaties als agency theory (Deci et al., 1999; Eisenberger en Cameron, 1996). Dit komt doordat deze vorm van belonen de autonomie van een individu over het algemeen in zijn waarde laat en daardoor meestal geen negatief effect heeft op iemands intrinsieke motivatie. $^{4}$

\subsection{Methode}

Het theoretische verklarende model is getest op basis van hetzelfde vragenlijstonderzoek als in paragraaf 3 . Er waren 86 paren die alle voor dit model relevante vragen hadden ingevuld. In dit model is de onafhankelijke variabele gemeten bij de medewerkers en zijn de andere variabelen gemeten bij de leidinggevenden. Wederom werd gebruikgemaakt van structural equation modeling om de hypotheses te toetsen en er zijn weer een groot aantal controles uitgevoerd om te checken of de gevonden resultaten robuust zijn.

De mate waarin medewerkers betrokken zijn bij de ontwikkeling van de prestatie-indicatoren waarmee hun prestatie gemeten wordt en de prestaties van medewerkers werden op precies dezelfde wijze gemeten als in het onderzoek van paragraaf 3 . Voor de kwaliteit van de prestatie-indicatoren werd ook dezelfde schaal gebruikt, maar nu ingevuld door leidinggevenden in plaats van medewerkers, en één item dat minder relevant was voor leidinggevenden is eruit weggelaten (Cronbachs alfa $=0,72$ ). De mate waarin de leidinggevenden de prestatie-indicatoren gebruiken als basis van de verschillende soorten beloningen is gemeten met de schaal van Moers (2006), met uitzondering van één item waarvoor zowel in de pretest als na de echte meting bleek dat hij niet goed bij de schaal 
paste. Cronbachs alfa was 0,84 voor het gebruik van de prestatie-indicatoren voor geldelijk belonen; 0,88 voor niet-geldelijk belonen; en 0,89 voor evaluaties en discussies.

\subsection{Bevindingen}

De resultaten van onze analyses staan in figuur 2. Wederom wijzen de robuustheidscontroles op dezelfde conclusies. De data ondersteunen hypothese 1: als medewerkers worden betrokken bij de ontwikkeling van prestatieindicatoren, vinden leidinggevenden deze indicatoren gemiddeld van hogere kwaliteit. Verder blijkt dat leidinggevenden kwalitatief goede prestatie-indicatoren vaker gebruiken als basis voor de beloning van medewerkers (hypotheses $2 \mathrm{t} / \mathrm{m} 4$ ). Daarnaast was er een positief verband tussen verbale beloningen in de vorm van evaluaties of discussies en medewerkersprestaties. Dit komt overeen met hypothese 7. Er is geen verband gevonden voor de andere beloningsvormen met prestatie, waardoor zowel hypothese 5 en 6 als de alternatieve hypotheses $5 \mathrm{a}$ en $6 \mathrm{a}$ niet ondersteund worden. Samengevat betekent dit dat leidinggevenden medewerkersprestaties kunnen stimuleren door samen met medewerkers prestatie-indicatoren te ontwikkelen om zo de kwaliteit van de prestatie-indicatoren te verbeteren en deze indicatoren vervolgens te gebruiken als basis voor evaluaties van en discussies met medewerkers.

\section{Discussie}

De drie studies wijzen uit dat het samen met medewerkers ontwikkelen van prestatie-indicatoren op verschillende manieren tot betere medewerkersprestaties kan leiden. Allereerst zorgt deze ontwikkelmethode ervoor dat de kwaliteit van de prestatie-indicatoren beter wordt, zowel voor de medewerkers als voor hun leidinggevenden. Kwalitatief goede prestatie-indicatoren stellen medewerkers in staat om beter te presteren. Daarnaast geven ze leidinggevenden een goed instrument om de discussie aan te gaan met medewerkers. Beide leiden tot betere prestaties van medewerkers.

\subsection{Bijdrage aan de theorie}

De combinatie van methoden van dit onderzoek leverde veel inzicht op in waarom medewerkers beter gaan presteren als ze worden betrokken bij het ontwikkelen van de prestatie-indicatoren waarmee hun prestatie gemeten wordt. Het actie-onderzoek liet zien hoe deze prestatieverbetering in de praktijk tot stand komt en liet zien dat er sprake was van causaliteit: eerst werden prestatie-indicatoren gemaakt samen met medewerkers en pas daarna vonden de positieve effecten op medewerkersgedrag en afdelingsprestatie plaats. De studie van paragraaf 3 maakte het mogelijk om de resultaten uit het actie-onderzoek statistisch te toetsen voor een brede steekproef bestaande uit medewerkers en leidinggevenden in allerlei soorten banen, organisaties en branches. Paragraaf 4 voegt nog een tweede verklaring toe aan de gevonden verklaring voor het verband tussen samen prestatie-indicatoren ontwikkelen en medewerkersprestaties door ook vanuit het perspectief van de leidinggevende tegen dit vraagstuk aan te kijken. Als de modellen uit paragraaf 3 en 4 tegelijkertijd getoetst worden, blijkt dat ze allebei significant blijven en ze voegen dus allebei iets toe.

\subsection{Bijdrage aan de praktijk}

De resultaten van dit onderzoek geven een idee van hoe invloed van medewerkers op het ontwerp van prestatieindicatoren kan leiden tot betere medewerkersprestaties. Alle drie de studies laten zien dat de kwaliteit van de prestatie-indicatoren hoger is als deze samen met medewerkers tot stand zijn gekomen, doordat dan gebruik wordt gemaakt van de waardevolle kennis van medewerkers over hun werk. Volgens deze studies hebben kwalitatief goede prestatie-indicatoren verschillende voordelen. Allereerst zorgen ze dat medewerkers positiever denken over presteren, dat ze meer sociale druk voelen om te presteren en dat ze zich beter in staat voelen om te presteren. Uit dit onderzoek blijkt dat die laatste het belangrijkste is om medewerkersprestaties te beïnvloeden, dus organisaties kunnen zich het beste hierop richten. Dit kunnen zij doen door medewerkers goed te faciliteren in hun werk en barrières zoveel mogelijk op te lossen.

Een tweede voordeel van kwalitatief goede prestatie-indicatoren is dat ze beter gebruikt kunnen worden om medewerkers mee te sturen. Overigens blijkt uit dit onderzoek dat het niet noodzakelijk positief is om medewerkers te belonen in de vorm van salarisverhogingen, bonussen of promoties. Dit kan ook negatief uitwerken. De resultaten van dit onderzoek suggereren dat organisaties er beter voor kunnen kiezen om de prestatie-indicatoren te gebruiken als basis voor discussies en evaluaties.

Tot slot heeft dit onderzoek meer inzicht opgeleverd in hoe prestatie-indicatoren ontwikkeld kunnen worden samen met medewerkers. Een voorbeeld van een succesvol ontwikkelingsproces is gegeven in paragraaf 2.2.

\subsection{Beperkingen en suggesties voor verder onderzoek}

Een eerste beperking van dit onderzoek is dat het directe verband tussen samen prestatie-indicatoren maken en prestaties dat verwacht werd op basis van eerdere studies - waaronder die van paragraaf 2 - in de vragenlijstonderzoeken niet gevonden werd. Wellicht komt dat doordat de manier waarop we participatie in het ontwikkelen van prestatie-indicatoren gemeten hebben, ook ruimte laat voor zwakkere vormen van participatie. Waarschijnlijk is niet zomaar iedere manier van medewerkers betrekken bij de ontwikkeling van prestatie-indicatoren voldoende, maar is een uitgebreid ontwikkelingsproces nodig - zoals die van paragraaf 2.2 - om daadwerkelijk prestatieverbeteringen te bewerkstelligen. Of dit inderdaad verklaart waarom het vragenlijstonderzoek geen direct verband liet zien, moet nog verder onderzocht worden. Bovendien is 
nog meer onderzoek nodig naar welke onderdelen van het ontwikkelingsproces nu echt noodzakelijk zijn voor positieve resultaten en welke minder.

Een tweede beperking van de studies is dat de gevonden resultaten per situatie kunnen verschillen. In de vragenlijstonderzoeken is gebruik gemaakt van een erg brede populatie, met als doel uit te vinden hoe medewerkersprestaties in het algemeen kunnen verbeteren als je medewerkers betrekt bij de ontwikkeling van prestatie-indicatoren. Het nadeel van zo'n brede populatie, is dat je geen uitspraken kunt doen voor specifieke gevallen. Gebaseerd op de gebruikte theorieën is de kans aanzienlijk dat het mechanisme in specifieke situaties anders werkt. Voor we zeker weten of dit het geval is en welke gevolgen dit heeft is hier eerst meer onderzoek naar nodig. Organisaties die medewerkersprestaties willen verbeteren door samen met hen prestatie-indicatoren te maken, kunnen beter eerst onderzoeken welke factoren in die betreffende organisatie het belangrijkst zijn om te beïnvloeden.

In dit artikel zijn twee verklaringen onderzocht voor de relatie tussen samen prestatie-indicatoren ontwikkelen en medewerkersprestaties. Natuurlijk betekent dit niet dat alle mogelijke mechanismen zijn onderzocht. In anders studies over participatie in het algemeen en specifiek op het gebied van goal setting en budgetparticipatie zijn andere mogelijk relevante verklaringen gevonden, zoals gevoel van eerlijkheid en vertrouwen. Toekomstig onderzoek moet uitwijzen of deze verklaringen ook relevant zijn voor deze specifieke vorm van participatie.

Dr. Ir. Bianca A.C. Groen is universitair docent Management

Accounting aan de Universiteit van Amsterdam. Ze

promoveerde dit jaar aan de Universiteit Twente en heeft

daarvoor technische bedrijfskunde en arbeids- en

organisatiepsychologie gestudeerd.

Dit artikel is een samenvatting van haar proefschrift

"Enabling employees through co-development of

performance measures". Meer details over de onderzoeken

zijn in dit proefschrift te vinden. De genoemde onderzoeken

zijn tot stand gekomen in nauwe samenwerking met

promotoren prof. dr. ir. Marc J. F. Wouters en prof. dr.

Celeste P. M. Wilderom.

\section{Noten}

Voor meer details over het onderzoek uit deze paragraaf wordt verwezen naar Groen, Wouters en Wilderom (2012).

2. In een brainwrite krijgt iedereen een formulier met daarop een concrete verbetervraag. In tien minuten schrijft iedereen zoveel mogelijk verbeterideeën op. Daarna geven ze hun formulier door aan degene naast hen. Zo krijgt men weer tien minuten om de ideeën door te lezen en nieuwe ideeën aan te dragen. Dit gaat zo door totdat iedereen zijn eigen formulier weer voor zich heeft.

3 De vragenlijst is ingevuld door 25 monteurs. Medewerkersinitiatief werd gemeten met de uit zeven items bestaande schaal van Frese en Fay (2003, p. 14; Cronbachs alfa =0,79). De schalen voor attitude, norm en control zijn geconstrueerd op basis van de richtlijnen die er zijn voor het ontwikkelen van theory-of-planned-behaviorvragenlijsten (Darker \& French, 2009; Fishbein \& Ajzen, 2010; Francis et al., 2004). Attitude en norm werden gemeten met drie items (Cronbachs alfas waren 0,91 en 0,66) en control met twee items (Cronbachs alfa $=0,36$ en een robuustheidscontrole voor het beste item leidt tot dezelfde resultaten).

4. Hierbij moet overigens worden opgemerkt dat als in de boodschap van de leidinggevende duidelijke controle-elementen schuilgaan, ook verbale beloningen de motivatie kunnen verkleinen (Deci, Koestner, \& Ryan, 1999).

\section{Literatuur}

- Abernethy, M.A. en J. Bouwens (2005), Determinants of accounting innovation implementation, Abacus, vol. 41, no. 3, pp. 217-240.

- Ajzen, I. (1991), The theory of planned behavior, Organizational Behavior and Human Decision Processes, vol. 50, no. 2, pp. 179211.

- Ajzen, I. (2012), Martin Fishbein's legacy: The reasoned action approach, The ANNALS of the American Academy of Political and Social Science, vol. 640, no. 1, pp. 11-27.

- Baskerville, R. en A.T. Wood-Harper (1998), Diversity in information systems action research methods, European Journal of Information Systems, vol. 7, pp. 90-107.

- Burney, L.L., C.A. Henle en S.K. Widener (2009), A path model examining the relations among strategic performance measurement system characteristics, organizational justice, and extra- and in-role performance, Accounting, Organizations and Society, vol. 34, pp. 305-321.

- Coughlan, P. en D. Coghlan (2002), Action research for operations management, International Journal of Operations and Production Management, vol. 22, no. 2, pp. 220-240.
- Darker, C.D. en D. French (2009), What sense do people make of a theory of planned behaviour questionnaire? A think-aloud study, Journal of Health Psychology, vol. 14, no. 7 , pp. 861-871.

- Deci, E.L., R. Koestner en R.M. Ryan (1999), A meta-analytic review of experiments examining the effects of extrinsic rewards on intrinsic motivation, Psychological Bulletin, vol. 125, no. 6, pp. 627-668.

- Eisenberger, R. en J. Cameron (1996), Detrimental effects of reward: Reality or myth? American Psychologist, vol. 51, no. 11, pp. 1153-1166. 
- Eisenhardt, K.M. (1989), Agency theory: An assessment and review, Academy of Management Review, vol. 14, no. 1, pp. 57-74.

- Erez, M. en R. Arad (1986), Participative goalsetting: Social, motivational, and cognitive factors, Journal of Applied Psychology, vol. 71, no. 4, pp. 591-597.

- Falk, A. en M. Kosfeld (2006), The hidden costs of control, The American Economic Review, no. 96, vol. 5, pp. 1611-1630.

- Fishbein, M. en I. Ajzen (2010), Predicting and Changing Behavior, New York: Psychology Press, Taylor \& Francis Group.

- Francis, J.J., M.P. Eccles, M. Johnston, A. Walker, J. Grimshaw, R. Foy, et al. (2004), Constructing questionnaires based on the theory of planned behavior: A manual for health services researchers, Retrieved June 25, 2008, from http://www.rebeqi.org/ ViewFile.aspx?itemlD=212

- Frese, M. en D. Fay (2003), Measuring personal initiative, bezocht op 3 april 2009 via http://www.uni-giessen.biz/content/ downloads/measurement/InterviewPerslnit.pdf

- Gagné, M. en E.L. Deci (2005), Selfdetermination theory and work motivation, Journal of Organizational Behavior, vol. 26, pp. 331-362.

- Groen, B.A.C. (2012), Enabling employees through co-development of performance measures, proefschrift Universiteit Twente.

- Groen, B.A.C., M.J.F. Wouters en C.P.M. Wilderom (2012), Why do employees take more initiative if they develop their own performance measures? A field study, Management Accounting Research, vol. 23, no. 1, pp. 120-141.

- Hunton, J.E. en D. Gibson (1999), Soliciting user-input during the development of an accounting information system: Investigating the efficacy of group discussion, Accounting, Organizations and Society, vol. 24, pp. 597618.
- Jeong, S.B. (2006), Participation and goal setting: An examination of the components of participation, Ohio: Ohio State University.

- Kasanen, E., K. Lukka en A. Siitonen (1993), The constructive approach in management accounting research, Journal of Management Accounting Research, vol. 5, pp. 243-264.

- Kleingeld, A., H. Van Tuijl en J.A. Algera (2004), Participation in the design of performance management systems: A quasiexperimental field study, Journal of Organizational Behavior, vol. 25, pp. 831-851.

- Kunz, A.H. en D. Pfaff (2002), Agency theory, performance evaluation, and the hypothetical construct of intrinsic motivation, Accounting, Organizations and Society, vol. 27, pp. 275295.

- Lambert, R.A. (2007), Agency theory and management accounting, in C.S. Chapman, A.G. Hopwood en M.D. Shields (redactie), Handbook of Management Accounting Research, Elsevier, Amsterdam, vol. 1, pp. 251-272.

- Latham, G.P., D.C. Winters en E.A. Locke (1994), Cognitive and motivational effects of participation: A mediator study, Journal of Organizational Behavior, vol. 15, pp. 49-63.

- Moers, F. (2006), Performance measure properties and delegation, The Accounting Review, vol. 81, no. 4, pp. 897-924.

- Neely, A.D., M. Bourne, J. Mills, K. Platts en H. Richards (2002), Getting the measure of your business, Cambridge: University Press.

- Neely, A.D., M. Gregory en K. Platts (1995), Performance measurement system design: A literature review and research agenda, International Journal of Operations and Production Management, vol. 15, no. 4, pp. 80-116.

- Neely, A.D., H. Richards, J. Mills, K. Platts en M. Bourne (1997), Designing performance measures: A structured approach, International
Journal of Operations and Production

Management, vol. 17, no. 11, pp. 1131-1152.

- Podsakoff, P.M. en S.B. Mackenzie (1989), A second generation measure of organizational citizenship behavior, Indiana University, Bloomington.

- Ryan, R.M. en E.L. Deci (2000), SelfDetermination Theory and the facilitation of intrinsic motivation, social development, and well-being, American Psychologist, vol. 55, no. 1. pp. 68-78.

- Salganik, M.J. en D.D. Heckathorn (2004), Sampling and estimation in hidden populations using respondent-driven sampling, Sociological Methodology, vol. 34, pp. 193239 .

- Schein, E. (1987), The clinical perspective in fieldwork, Newbury Park (NJ): Sage.

- Wagner, J.A., C.R. Leana, E.A. Locke en D.M. Schweiger (1997), Cognitive and motivational frameworks in US research on participation: A meta-analysis of primary effects, Journal of Organizational Behavior, vol. 18, pp. 49-65.

- Williams, L J. en S.E. Anderson (1991), Job satisfaction and organizational commitment as predictors of organizational citizenship and inrole behaviors, Journal of Management, vol. 17, no. 3, pp. 601-617.

- Wong-On-Wing, B., L. Guo en G. Lui (2010), Intrinsic and extrinsic motivaiotn and participation in budgeting: Antecedents and consequences, Behavioral Research in Accounting, vol. 22, no. 2, pp. 133-153.

- Wouters, M.J.F. (2009), A developmental approach to performance measures: Results from a longitudinal case study, European Management Journal, vol. 27, pp. 64-78.

- Wouters, M.J.F. en C.P.M. Wilderom (2008), Developing performance-measurement systems as enabling formalization: A longitudinal field study of a logistics department, Accounting, Organizations and Society, vol. 33, pp. 488-516. 